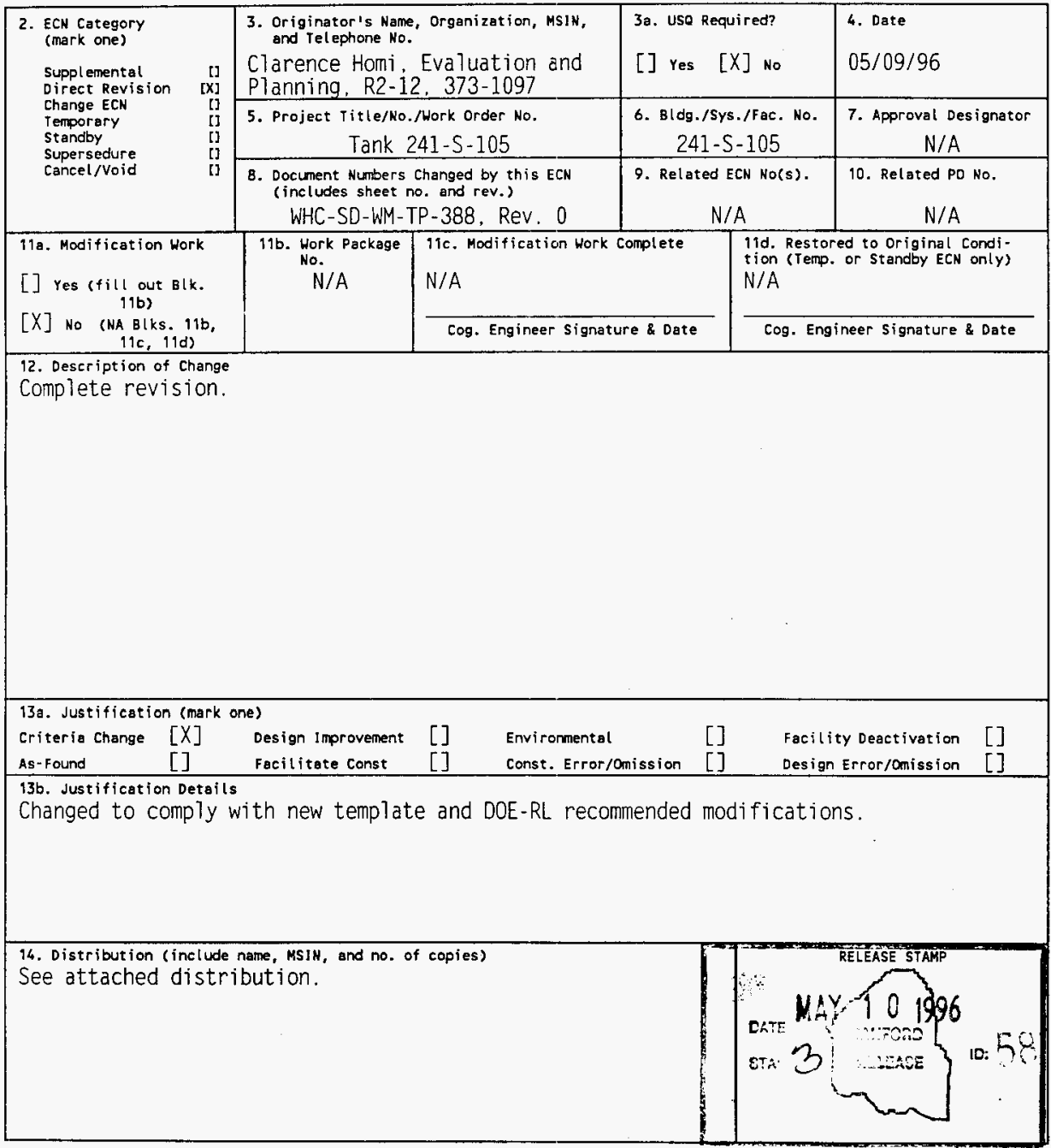

A-7900-013-2 (11/94) GEF095 


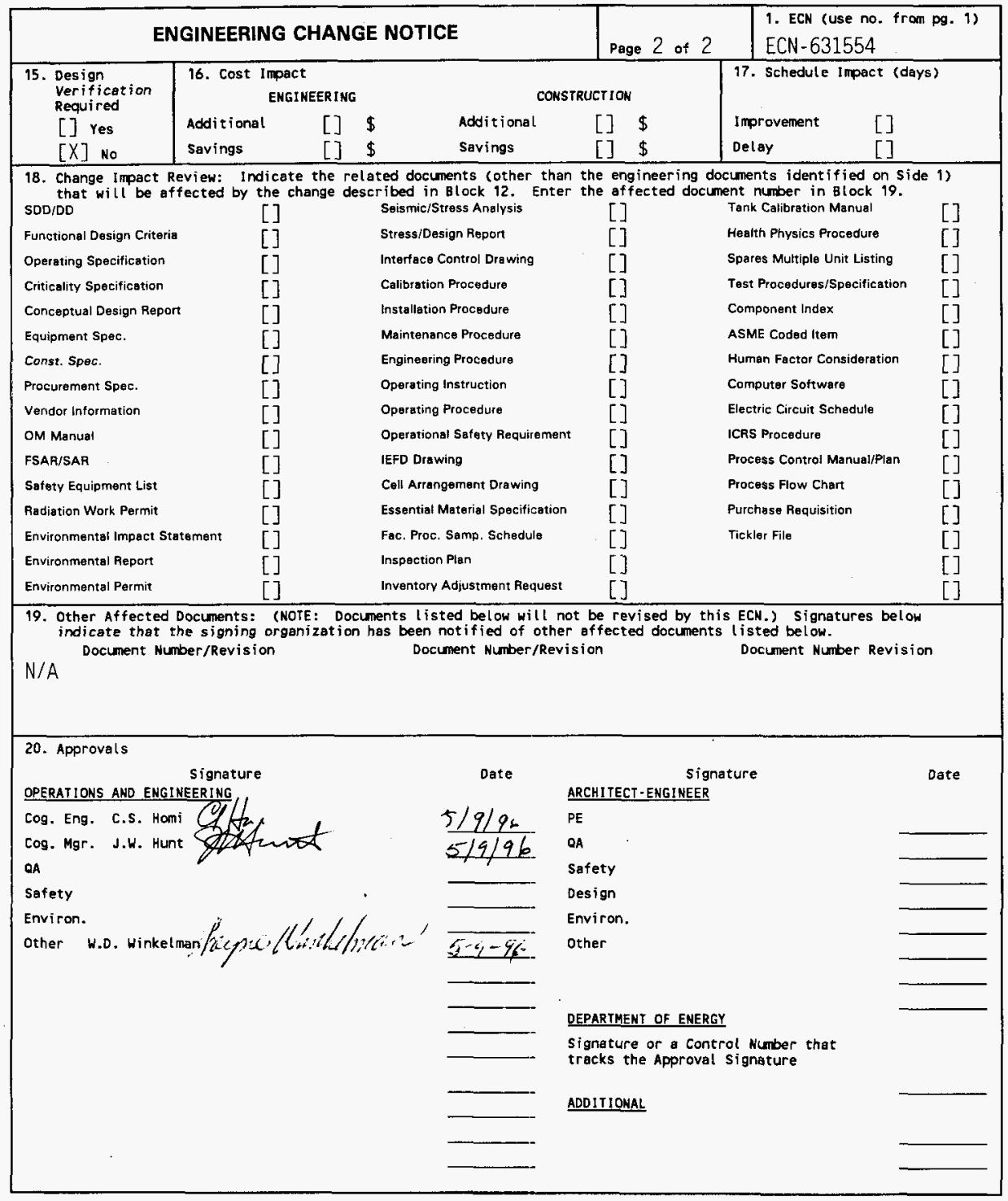




\section{Tank 241-S-105 Tank Characterization Plan}

C. S. Homi

Westinghouse Hanford Company, Richland. WA 99352

U.S. Department of Energy Contract DE-AC06-87RL10930

EDT/ECN: ECN-631554 UC: 2070

Org Code: 79200

Charge Code: N4G6A

B\&R Code: EW 3120074 Tota1 Pages: 7

Key Words: Characterization, General Safety Issues, Specific Safety Issues, Information Requirements, Schedule

Abstract: This document is a plan that identifies the information needed to address relevant issues concerning short-term and long-term storage and long-term management of single-shel1 tank 241-S-105.

TRADEMARK DISCLAIMER. Reference herein to any specific commercial product, process, or service by trade name, trademark, manufacturer, or otherwise, does not necessarily constitute or imply its endorsement, recommendation, or favoring by the United States Government or any agency thereof or its contractors or subcontractors.

Printed in the United States of America. To obtain copies of this document, contact: WHC/BCS Document Control Services, P.O. Box 4970, Mailstop H6-08, Richland HA 99352, Phone (509) 372-2420; Fax (509) 376-4989.
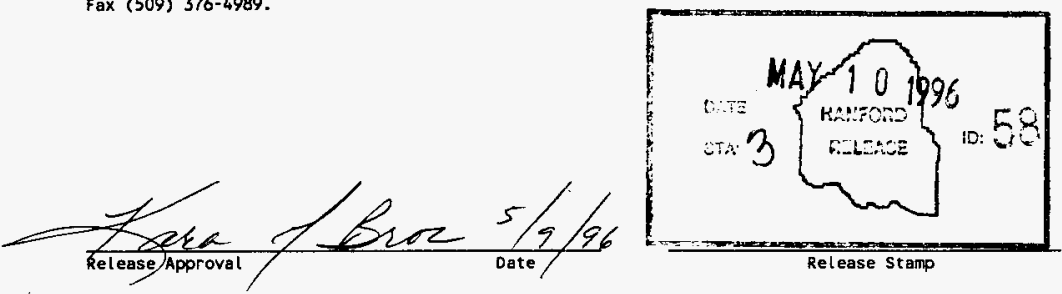

\section{Approved for Public Release}


RECORD OF REVISION

(2) Title

Tank 241-S-105 Tank Characterization Plan

CHANGE CONTROL RECORD

\begin{tabular}{|c|c|c|c|}
\hline \multirow{2}{*}{ (3) Revision } & \multirow{2}{*}{ (4) Description of Change - Replace, Add, and Delete Pages } & \multicolumn{2}{|c|}{ Authorized for Release } \\
\hline & & (5) Cog. Engr. & (6) Cog. Mgr. \\
\hline 0 & $\begin{array}{l}\text { (7) Initially released } 08 / 28 / 95 \text { on EDT- } \\
613370 \text {. }\end{array}$ & C.S. Homi & S.J. Eberlein \\
\hline RS 1 & Incorporate per ECN-631554. & C.S. Homi & J.W. Hunt \\
\hline & & & $5 x<1019$ \\
\hline & & & \\
\hline & & & \\
\hline & & & \\
\hline & & & \\
\hline & & & \\
\hline & & & \\
\hline & & & \\
\hline & & & \\
\hline & & & \\
\hline & & & \\
\hline & & & \\
\hline & & & \\
\hline & & & \\
\hline & & & \\
\hline & & & \\
\hline & & & \\
\hline & & & \\
\hline & & & \\
\hline & & & \\
\hline & & & \\
\hline & & & \\
\hline & & & \\
\hline & & & \\
\hline & & & . \\
\hline & & & \\
\hline & & & \\
\hline & & & \\
\hline & & & \\
\hline & & & \\
\hline & & & \\
\hline
\end{tabular}


WHC-SD-WM-TP-388

Revision 1

UC-2070

\section{Tank 241-S-105 Tank Characterization Plan}

W. D. Winkelman

Westinghouse Hanford Company

Date Published

May 1996

Prepared for the U.S. Department of Energy

Office of Environmental Restoration and

Waste Management

\section{Westinghouse Hanford Company Richand, Wastinizeon}

Management and Operations Contractor for the

U.S. Department of Energy under Contract DE-AC06-87RL10930 
WHC-SD-WM-TP-388, REV 1

TABLE OF CONTENTS

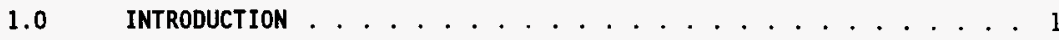

2.0 PROGRAM ELEMENTS REQUIRING INFORMATION FOR TANK 24I-S-105 ... 1

2.1 GENERAL SAFETY ISSUES $\ldots \ldots \ldots \ldots \ldots$

2.2 SPECIFIC SAFETY ISSUES . . . . . . . . . . . . 2

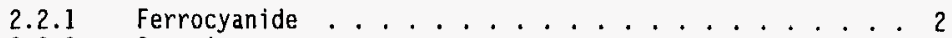

2.2 .2 Organic ................. 2

2.2 .3 High Heat ............... 2

2.2 .4 Flammable Gas .................. 2

2.2 .5 Vapor.................. 2

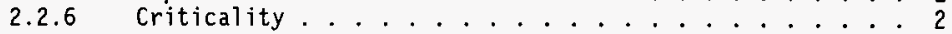

2.3 CONTINUING OPERATIONS . . . . . . . . . . . . . . 3

2.3.1 Compatibility/Stabilization .......... 3

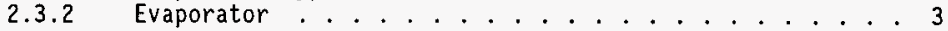

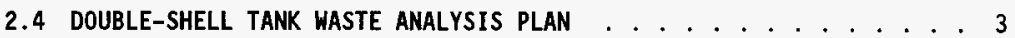

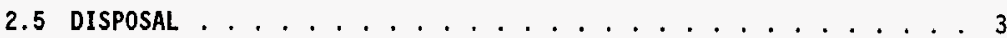

2.5.1 Retrieval ............... 3

2.5.2 Pretreatment/Vitrification . . . . . . 3

2.6 HISTORICAL MODEL EVALUATION . . . . . . . . . . . . 3

3.0 HOW INFORMATION WILL BE OBTAINED .............. 3

4.0 PRIORITY OF INFORMATION REQUIREMENTS ............ . 4

5.0 WHEN INFORMATION WILL BE AVAILABLE ............ 4

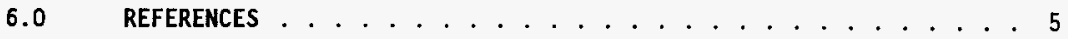

\section{LIST OF TABLES}

4-1 Integrated DQO Requirements and Priorities ......... 4 


\section{WHC-SD-WM-TP-388, REV 1}

\subsection{INTRODUCTION}

This Tank Characterization Plan (TCP) identifies the information needed to address relevant issues concerning short-term and long-term safe storage and long-term management of single shell tank 24l-S-105 (S-105). It should be understood that the various needs and issues surrounding tank S-105 are evolving as new information about the tank is uncovered. As a result of this progression, this TCP addresses only the issues that, to this date, have been identified. It is expected that deviations from this plan may occur as additional issues or needs arise which impact the management of tank S-105. As necessary, this TCP will be revised to reflect those changes or deviations. This plan reflects the best information availabie as of May 1996.

Tank S-105 was constructed between 1943 and 1944 and put into service in 1953. Tank S-105 was filled with waste from the Reduction Oxidation (REDOX) facility from the second quarter of 1953 until the third quarter of 1973. The tank was removed from service in 1976, labeled inactive in 1978, primary stabilized in June 1979, partially isolated in December 1982, and jet pumped/interim stabilized in September 1988. Intrusion prevention was completed in September 1990. The tank is categorized as sound. Tank S-105 is equipped to cascade to Tank 241-S-106 and is second in the three-tank cascade series. (Brevick et a1. 1995)

This tank currently contains waste with a total waste volume of $1726 \mathrm{~kL}$ (456 $\mathrm{kgal}$, which is equivalent to $440 \mathrm{~cm}(173 \mathrm{in})$ of waste as measured from the baseline of the tank (Hanlon 1996).

This tank is not on any watch List.

Near-term sampling and analysis activities are focused on either verifying or changing the Watch List tank status, and identifying any new safety issues. Should any safety issues be identified, additional analysis will occur consistent with the identified issue.

In addition to the resolution of the safety issues, it is intended that all tank waste will be subject to pretreatment and retrieval to prepare for final storage or disposal. Presently, these long-range plans have yet to be fully identified and are, therefore, not included in this document.

\subsection{PROGRAM ELEMENTS REQUIRING INFORMATION FOR TANK 241-S-105}

This section identifies the various program elements, and identifies which of these programs require characterization data from tank S-105.

\subsection{GENERAL SAFETY ISSUES}

The Tank Safety Screening Data Quality Objective (Dukelow et al. 1995) describes the sampling and analytical requirements that are used to screen waste tanks for unidentified safety issues. The analytical requirements for the safety screening of a tank are energetics, total alpha activity, moisture content, density, and flammable gas concentration. 


\section{WHC-SD-WM-TP-388, REV 1}

\subsection{SPECIFIC SAFETY ISSUES}

\subsubsection{Ferrocyanide}

This tank is not on the Ferrocyanide Watch List; therefore, no information needs are currently identified for this program element.

\subsubsection{Organic}

This tank is not on the Organic Watch List; therefore, no information needs are currently identified for this program element.

\subsubsection{High Heat}

This tank is not on the High Heat Watch List; therefore, no information needs are currently identified for this program element.

\subsubsection{Flammable Gas}

This tank is not on the Flammable Gas Watch List; therefore, no information needs are currently identified for this program element.

\subsubsection{Vapor}

A11 177 underground tanks must be vapor-sampled for organic solvent screening as per Recommendation 93-5 Implementation Plan (DOE-RL 1996). Some tanks may require additional vapor sampling due to other program needs. These tanks may be classified into four categories: (1) those tanks which are to be rotary mode core sampled (as a consequence of the rotary sampling system exhauster permit requirements); (2) tanks on the Organic or Ferrocyanide Watch Lists; (3) tanks in $C$ farm; and (4) tank 241-BX-104, due to vapor exposure. Information needs must satisfy Data Quality Objectives for Tank Hazardous Vapor Safety Screening (Osborne and Buckley 1995), and for rotary mode only, Rotary Core Vapor Sampling Data Quality Objective (Price 1994), and Data Quality Objective for Regulatory Requirements for Hazardous and Radioactive Air Emissions Sampling and Analysis (Mulkey and Markillie 1995) as amended by Status of the Current Understanding of the Toxic Air Pollutants (TAPS) and Hanford Tank Farm Vapor Space Characterization; Recommended Path Forward and Justification for Cont inued RMCS Exhauster Operations (Laws 1996).

Tank S-105 was vapor sampled in December 1995 in support of Osborne et al. (1995).

\subsubsection{Criticality}

No information separate from that for the general safety issue of tank S-105 are currently identified for this program element. However, if the general safety screening of tank S-105 identifies a potential criticality concern, analyses for fissile materials and neutron sorbers and poisons will be performed as identified in the safety screening data quality objective (DQO). 
WHC-SD-WM-TP-388, REV 1

\subsection{CONTINUING OPERATIONS}

\subsubsection{Compatibility/Stabilization}

This section does not apply to tank S-105.

\subsubsection{Evaporator}

This section does not apply to tank S-105.

\subsection{DOUBLE-SHELL TANK WASTE ANALYSIS PLAN}

This section does not apply because tank S-105 is a single-shell tank.

\subsection{DISPOSAL}

\subsubsection{Retrieval}

Current retrieval needs (B10om and Nguyen 1995) do not call for test samples to be taken from tank S-105.

\subsubsection{Pretreatment/Vitrification}

Tank S-105 has not been identified as a bounding tank for pretreatment/ disposal process development strategy (Kupfer et a1. 1995). A11 tanks were prioritized using the pretreatment strategy in the Tank Waste Characterization Basis (Brown et a1. 1995) document and a portion of archive sample material could be used for pretreatment testing if available. The strategy does not require any specific analyses to be done on the samples.

\subsection{HISTORICAL MODEL EVALUATION}

This tank is identified as an acceptable alternative for bounding tank 241-U-109 in Historical Model Evaluation Data Requirements (Simpson and McCain 1995). The applicability of these analyses will be determined based on tank 241-U-109's sampling and analysis and will be documented in the tank specific sample and analysis plan.

\subsection{HOW INFORMATION WILL BE OBTAINED}

The number of samples required to characterize a tank is a function of waste heterogeneity and the desired confidence to make a correct decision. directed by the safety screening $\mathrm{DQO}$, if inadequate information exists to determine an appropriate number of samples, two vertical profiles will be obtained. These vertical profiles may be obtained using core, auger (for shallow tanks), or grab samples. If analysis of these profiles reveals that additional profiles are necessary to meet data needs, more sample profiles will be requested. Prior to rotary sampling it is necessary to vapor sample the tank per the requirements of Rotary Core Vapor Sampling Data Quality objective (Price 1994). 
WHC-SD-WM-TP-388, REV 1

\subsection{PRIORITY OF INFORMATION REQUIREMENTS}

Vapor sampling was completed in December 1995 and rotary mode core sampling is scheduled for June 1997 (Stanton 1996). Refer to Table 4-1 for the current $\mathrm{DQO}$ requirements and planned sampling and analytical requirements.

Table 4-1: Integrated DQO Requirements and Priorities

\begin{tabular}{|c|c|c|c|}
\hline $\begin{array}{c}\text { Sampling } \\
\text { Event }\end{array}$ & Applicable Issues & Sampling Requirements ${ }^{*}$ & $\begin{array}{l}\text { Analytical } \\
\text { Requirements }\end{array}$ \\
\hline $\begin{array}{l}\text { Vapor } \\
\text { Sampling }\end{array}$ & $\begin{array}{l}\text {-Organic Solvent } \\
\text { Layer 93-5 Vapor } \\
\text { Issue } \\
\text { - Rotary Mode } \\
\text { Sampl ing DQO } \\
\text {-Hazardous Vapor DQO }\end{array}$ & $\begin{array}{l}\text { Steel canisters, Triple } \\
\text { Sorbent Traps, Sorbent } \\
\text { Trap Systems. }\end{array}$ & $\begin{array}{l}\text { Flammable Gas } \\
\text { Organic Vapors } \\
\text { Permanent Gases }\end{array}$ \\
\hline $\begin{array}{l}\text { Rotary } \\
\text { Mode Core } \\
\text { Sampling }\end{array}$ & -Safety Screening DQO & $\begin{array}{l}\text { Core samples from } 2 \\
\text { risers separated } \\
\text { radially to the maximum } \\
\text { extent possible } \\
\text { Combustible gas } \\
\text { measurement }\end{array}$ & $\begin{array}{l}\text { Flammability, } \\
\text { Energetics, Moisture, } \\
\text { Total alpha activity, } \\
\text { Density }\end{array}$ \\
\hline
\end{tabular}

* Consult each applicable DQO in force at the time for analytical requirements.

\subsection{WHEN INFORMATION WILL BE AVAILABLE}

According to Stanton (1996), data are expected to be available from the rotary mode core sampling event for tank S-105 in 0ctober 1997. This time may be altered if the sampling schedule changes. Data are available from the December 1995 vapor sampling. 


\section{WHC-SD-WM-TP-388, REV 1}

\subsection{REFERENCES}

Bloom, G. R. and Q. H. Nguyen, 1995, Characterization Data Needs for Development, Design and Operation of Retrieval Equipment Developed Through the Data Quality Objective Process, WHC-SD-WM-DQ0-008, Rev. 0, Westinghouse Hanford Company, Richland, Washington.

Brevick, C. H., L. A. Gaddis, and W. W. Pickett, 1995, Historical Tank Content Estimate for the Southwest Quadrant of the Hanford 200 West Areas, WHC-SD-WM-ER-352, Rev. 0, Westinghouse Hanford Company, Richland, Washington.

Brown, T.M., S. J. Eberlein, and T. J. Kunthara, 1995, Tank Waste Characterization Basis, WHC-SD-WM-TA-164, Rev. 1, Westinghouse Hanford Company, Richland, Washington.

DOE-RL, 1996, Recommendation 93-5 Implementation Plan, D0E/RL-94-0001, Rev. 1, U.S. Department of Energy, Richland, Washington.

Dukelow, G. T., J. W. Hunt, H. Babad, and J. E. Meacham, 1995, Tank Safety Screening Data Quality Objective, WHC-SD-WM-SP-004, Rev. 2, Richland, Washington.

Hanlon, B.M., 1996, Waste Tank Summary for Month Ending January 31, 1996, WHC-EP-0182-94, Westinghouse Hanford Company, Richland, Washington.

Kupfer, M. J., W. W. Schultz, and J. T. Slankas, 1995, Strategy for Sampling Hanford Site Tank Wastes for Development of Disposal Technology, WHC-SD-WM-TA-154, Rev. I, Westinghouse Hanford Company, Richland, Washington.

Laws, G. L., 1996, Status of the Current Understanding of the Toxic Air Pollutants (TAPS) and Hanford Tank Farm Vapor Space Characterization; Recommended Path Forward and Just ification for Continued RMCS Exhauster Operations, (telephone conference memorandum 01830-96-022, to Distribution, March 8), Westinghouse Hanford Company, Richland, Washington.

Mulkey, C.H., and K. D. Marki11ie, 1995, Data Quality Objective for Regulatory Requirements for Hazardous and Radioactive Air Emissions Sampling and Analysis, WHC-SD-WM-DQO-021, Rev. 0, Westinghouse Hanford Company, Rich1 and, Washington.

Osborne, J. W., and L. L. Buckley, 1995, Data Quality Objectives for Tank Hazardous Vapor Safety Screening, WHC-SD-WM-DQ0-002, Rev. 2, Westinghouse Hanford Company, Richland, Washington.

Osborne, J. W., J. L. Huckaby, E. R. Hewitt, C. M. Anderson, D. D. Mahlum, B. A. Pulsipher, and J. Y. Young, 1995, Data Qua7ity Objectives for Generic In-Tank Health and Safety Vapor Issue Resolution, WHC-SD-WM-DQO002, Rev. 2, Westinghouse Hanford Company, Richland, Washington. 
Price, D. N., 1994, Rotary Core Vapor Samp7ing Data Quality Objective, WHC-SD-WM-SP-003, Rev. 0, Westinghouse Hanford Company, Richland, Washington.

Simpson, B. C., and D. J. McCain, 1995, Historical Model Evaluation Data Requirements, WHC-SD-WM-DQO-018, Rev. OA, Westinghouse Hanford Company, Richland, Washington.

Stanton, G. A., 1996, Baseline Sampling Schedule, Change 96-02 (Internal Memo 75610-86-06 to Distribution, April 17), Westinghouse Hanford Company, Richland, Washington. 


\section{DISTRIBUTION SHEET}

\begin{tabular}{|c|c|c|c|c|c|c|}
\hline To & \multirow{2}{*}{\multicolumn{3}{|c|}{$\begin{array}{l}\text { From } \\
\text { Evaluation and Planning }\end{array}$}} & \multicolumn{3}{|c|}{ Page 1 of 1} \\
\hline Distribution & & & & \multicolumn{3}{|c|}{ Date $\quad 05 / 09 / 96$} \\
\hline \multicolumn{4}{|l|}{ Project Title/Work Order } & \multicolumn{3}{|c|}{ EDT No. N/A } \\
\hline \multicolumn{4}{|c|}{$\begin{array}{l}\text { WHC-SD-WM-TP-388, Rev. 1, "Tank 241-S-105 Tank Characterization } \\
\text { Plan" }\end{array}$} & \multicolumn{3}{|c|}{ ECN No. ECN-631554 } \\
\hline Name & MSIN & $\begin{array}{c}\text { Text } \\
\text { With } \\
\text { All } \\
\text { Attach. }\end{array}$ & Text on & & $\begin{array}{l}\text { Attach. } \\
\text { Appendix } \\
\text { Only }\end{array}$ & $\begin{array}{l}\text { EDT/ECN } \\
\text { Only }\end{array}$ \\
\hline
\end{tabular}

\section{ONSITE}

U. S. Department of Enerqy -

Richland Field office
W. Liou
N. W. Willis

$\begin{array}{ll}57-54 & x \\ S 7-54 & x\end{array}$

Westinghouse Hanford Company

G. D. Forehand

C. S. Homi

W. D. Winkelman

Central Files

T.C.R.C.

$\begin{array}{ll}S 7-21 & X \\ R 2-12 & X \\ R 2-12 & X \\ \text { A3 }-88 & X \\ \text { R2 }-12 & X\end{array}$

\section{OFFSITE}

U. S. Department of Enerqy - Headquarters

Office of Environmental Restoration and

Waste Management EM-563

12800 Middlebrook Road

Germantown, MD 20874

J. A. Poppiti 